\title{
KAJIAN KARAKTERISTIK DAN POTENSI KAWASAN KARST UNTUK PENGEMBANGAN EKOWISATA DI KECAMATAN PONJONG KABUPATEN GUNUNGKIDUL
}

\author{
Oleh \\ Fahad Nuraini ${ }^{1}$ dan Heru Pramono ${ }^{2}$ \\ ${ }^{1}$ Mahasiswa Program Pascasarjana Universitas Gadjah Mada \\ ${ }^{2}$ Jurusan Pendidikan Geografi FIS UNY \\ nurainifahad@yahoo.com
}

\begin{abstract}
Abstrak
Penelitian ini dilakukan di Kecamatan Ponjong dengan tujuan: (1) mengetahui karakteristik dan potensi kawasan karst untuk ekowisata, (2) merencanakan pengembangan ekowisata sebagai alternatif pengelolaan potensi dan pelestarian kawasan karst.Penelitian ini merupakan penelitian eksploratif. Populasi meliputi seluruh lahan karst (8.226 ha) dan seluruh kepala keluarga (13.787 KK). Sampel diambil pada empat zona yaitu utara, timur, tengah, dan selatan berdasarkan variasi bentuklahan karst. Pengambilan sampel fisik dengan teknik gugus dan purposif, sedangkan sampel masyarakat dengan kuota random. Data dikumpulkan dengan observasi dan wawancara serta dianalisis dengan analisis deskriptif, matching, dan SWOT. Hasil penelitian menunjukkan: (1) Karst Ponjong terbagi dalam kelas I dan II. Kelas I meliputi zona utara dengan nilai lanskap A dan kenampakan didominasi gua dan luweng, serta zona timur dengan nilai lanskap $B$ dan kenampakan didominasi bukit karst tipe kubah. Kelas II meliputi zona tengah dengan nilai lanskap $A$ dan kenampakan didominasi pemunculan air dan polje; serta zona selatan dengan nilai lanskap B dan kenampakan didominasi bukit tipe menara dan dolin. Karakteristik dan potensi non fisik Karst Ponjong antara lain:pada zona utara terdapat petilasan dan atraksi seni budaya;zona tengah berupa nilai sejarah; zona selatan berupa hasil pertanian dan kerajianan; sertazona timur berupa gua bernilai budaya dan pola kehidupan masyarakat tradisional. (2) desain ekowisata diawali dengan perencanaan pembangunan infrastruktur alami, konservasi bekas lahan tambang, perencanaan partisipasi masyarakat, dan ekowisata berkelanjutan. Selanjutnya kegiatan ekowisata diarahkan untuk wisata alam-pengetahuan di zona utara, wisata sejarahbudaya di zona tengah, wisata alam-konservasi di zona selatan, dan wisata rural-budaya di zona timur.
\end{abstract}

Kata kunci: karst, ekowisata, pelestarian karst, pengelolaan karst

\section{A STUDY ON THE CHARACTERISTICS AND POTENTIAL OF KARST REGION TO DEVELOP ECOTOURISM IN THE DISTRICT OF PONJONG GUNUNGKIDUL}

\begin{abstract}
This research was conducted in the District of Ponjong. The research aims to (1) know the characteristics and potential of karst region for ecotourism,(2) plan the development of ecotourism as an alternative for managing and conserving karst region. This research is an exploratory study. The population in this research include the entire karst regions (8,226 ha) and all family heads (13.787 households). The samples were taken from four zones, namely: the northern, eastern, central, and south based on variations of
\end{abstract}


karst land forms. The physical sampling technique was performed using purposive groups whereas the community sample was taken using quota random technique. The data were collected through observations and interviews. Then, they were analyzed using descriptive, matching, and SWOT analysis. The research findings show that: (1) Ponjong karst is divided into two classes i.e. I and II. Class I includes the northern zone with landscape value of $A$ and the appearance of a landscape is dominated by caves and ponds. Also, it includes the eastern zone with the value of $B$ and the appearance of the landscape is dominated by karst hills in the form of dome. Class II includes the central zone which has the value of $B$ and the appearance of a landscape is dominated by water spring and Polje. Moreover, it includes the south zone which has the value of $B$ and appearance of the landscape is dominated by hills in the form of tower and Dolin. Nonphysical characteristics and potential of Ponjong karst consist of: petilasan (past worshipping site) as well as art and cultural attractions at the northern zone; historic values at the central zones; agricultural and craft at the south zone; and cultural cave and traditional community life style at the eastern zone. (2) the design of ecotourism infrastructure was begun by planning the natural infrastructure development, conserving the former mining land, planning community participation, and sustaining ecotourism. Furthermore, ecotourism activities are directed to the nature-knowledge in the northern zone, the cultural-historic tourism in the central zone, the nature-conservation in the southern zone, and rural - cultural tour in the eastern zone.

Keywords: karst, ecotourism, preservation of karst, karst management

\section{PENDAHULUAN}

Kawasan karst merupakan kawasan dengan karakteristik khas sebagai hasil proses solusional, yang dicirikan dengan adanya cekungan tertutup, bukit-bukit kerucut, maupun lorong-lorong yang berfungsi sebagai sistem aliran bawah permukaan. Kawasan karst memiliki keunikan baik kenampakan fisik maupun kehidupan manusianya. Keunikan tersebut dapat dilihat dari bentanglahan yang spesifik dan berbeda dengan bentangahan lainnya, serta sistem kehidupan masyarakat yang terbentuk sebagai hasil adaptasi terhadap kondisi lingkungan fisik tersebut. Selain nilai keunikan bentanglahan, pada kawasan karst juga terdapat berbagai potensi sumberdaya. Namun demikian, dewasa ini kawasan karst banyak menghadapi ancaman kerusakan akibatpengeolaan yang kurang memperhatikan aspek kelestariannya.

Masih kurangnya pengetahuan masyarakat maupun informasi yang komprehensif mengenai kawasan karst menyebabkan timbulnya benturan antara kepentingan ekonomi dengan konservasi lingkungan (Haryono, 2000: 2). Kawasan karst di satu sisi memiliki kekayaan potensi dan sumberdaya yang berlimpah akan tetapi di sisi lain sangat rentan terhadap resiko kerusakan lingkungan. Sebelum kemerosotan fungsi kawasan karst mencapai titik paling rendah perlu dicari alternatif untuk mencegahnya, sehingga fungsi kawasan karst secara ekologi-sosial-ekonomi-kultural dan saintifik dapat dipertahankan. Pemilihan alternatif untuk melindungi fungsi kawasan karst perlu mendasarkan pada karakteristik kawasan karst dan potensinya (Sutikno dan Haryono, 2000: 1).

Berdasarkan karakteristik morfologinya, kawasan Karst di Kecamatan Ponjong termasuk dalam kategori karst yang telah mengalami perkembangan.Bukti-bukti 
perkembangan tersebut antara lain keberadaan doline, bukit karst, goa, dan sungai bawah tanah. Di Kecamatan Ponjong juga terdapat polje yang terbentuk oleh aktivitas sesar, yang berdampak pada banyaknya pemunculan air oleh karena munculnya sungai bawah tanah pada tekuk lereng bukit karst. Karst yang telah berkembang semakin tinggi potensi sumberdaya alamnya namun sekaligus semakin tinggi pula risiko kerusakannya. Untuk itu perlu disusun rekomendasi pengelolaan yang sesuai sehingga potensi sumberdaya yang ada dapat dimanfaatkan secara optimum namun fungsinya dapat dipertahankan agar tetap lestari.

Salah satu bentuk yang dapat diupayakan dalam pengelolaan kawasan karst berwawasan konservasi adalah dengan pengembangan ekowisata. Berbeda dengan kegiatan pariwisata pada umumnya yang justru menimbulkan kerusakan lingkungan,ekowisata memiliki konsep tersendiri dimana wisatawan yang menikmati keindahan alam diajak untuk memahami dan menghayati nilai-nilai serta dapat ditanamkan pemahaman dan kepedulian terhadap pelestarian lingkungan. Melalui pengembangan ekowisata diharapkan timbulnya rasa kepedulian untuk melestarikan sumberdaya kawasan karst. Kepedulian tersebut dapat timbul melalui pemahaman karst baik dari aspek saintifik (keilmuan) maupun phyosophical (penghayatan nilai dan makna) dengan tetap menikmati aspek estetik (keindahan), sesuai konsep dalam ekowisata (Baiquni, 2001)

\section{METODE PENELITIAN}

Penelitian ini merupakan penelitian eksploratif, menggunakan metode survei. Penelitian eksploratif digunakan sesuai dengan tujuan penelitian, yaitu dalam objek penelitian ini telah terdapat beberapa petunjuk yang mengindikasikan adanya permasalahan dan perlu dikembangkan lebih jauh. Metode survei menunjukkan cara pelaksanaan, yaitu mengumpulkan sejumlah besar data berupa variabel, unit atau individu dalam waktu yang bersamaan. Pendekatan yang digunakan adalah keruangan, kelingkungan dan kewilayahan.

Variabel dalam penelitian ini meliputi potensi fisik dan potensi non fisik. Potensi fisik meliputi morfologi eksokarst dan endokarst. Data untuk variabel potensi fisik diperoleh melalui observasi, studi pustaka, dan interpretasi foto udara Kecamatan Ponjong tahun 1993 skala 1:50.000. Potensinon fisik berupa kodisi sosial ekonomi budaya, kearifan lokal masyarakat, dan potensi SDM untuk pengeloaan ekowisata. Data untuk potensi non fisik diperoleh melalui wawancara dan observasi. Populasi meliputi seluruh lahan karst di Kecamatan Ponjong seluas 8.226 ha untuk aspek fisik, dan seluruh kepala keluarga di Kecamatan Ponjong sebanyak 13.787 KK untuk aspek non fisik. Sampel diambil pada empat zona yaitu utara, timur, tengah, dan selatan berdasarkan variasi bentuklahan karst. Pengambilan sampel fisik dengan teknik gugus dan purposif, sedangkan sampel masyarakat dengan kuota random.

Untuk menjawab rumusan masalah yang pertama digunakan analisis deskriptif dengan melakukan analisis kelas kawasan karst dan analisis lanskap. Analisis kelas kawasan dilakukan dengan mengacu pada Keputusan Menteri Energi dan Sumber Daya Mineral Nomor 1456.K/20/MEM/2000 yang membedakan kawasan karst menjadi kelas I, II, dan III berdasarkan fungsi dan kenampakannya. Analisis lanskap dilakukan dengan mengacu pada kriteria Bureau of Land Management dalam (Mannessa, 2008: 37 dengan modifikasi) yang membedakan kawasan karst menjadi kelas A (kualitas tinggi) kelas B (kualitas sedang), dan kelas $C$ (kualitas rendah) berdasarkan kelengkapan aspek-aspek 
bentanglahannya). Selanjutnya untuk menjawab rumusan masalah ke dua digunakan analisis pencocokan (matching), analisis deskriptif analitik, dan analisis SWOT.

\section{HASIL PENELITIAN DAN PEMBAHASAN}

\section{Daerah Penelitian}

Kecamatan Ponjong, Kabupaten Gunungkidul, Provinsi Daerah Istimewa Yogyakarta terletak pada $07^{\circ} 54^{\prime} 46^{\prime \prime}$ LS sampai $08^{\circ} 2^{\prime} 24^{\prime \prime}$ LS dan $110^{\circ} 41^{\prime} 0^{\prime \prime}$ BT sampai $110^{\circ} 46^{\prime} 0^{\prime \prime}$ BT. Luas wilayah Kecamatan Ponjong secara keseluruhan adalah 10.449 ha, sedangkan luas wilayah yang termasuk kawasan karst 8.226 ha. Secara geomorfologi regional Kecamatan Ponjong terletak pada bagian tengah Pegunungan Sewu yang berada pada Zona Selatan Jawa Timur. Sebelah utara dibatasi oleh Masif Panggung, sebelah Selatan dibatasi oleh Pegunungan Sewu, sebelah Timur dibatasi oleh Basin Baturetno, dan sebelah Barat dibatasi oleh Basin Wonosari (Gambar 1). Peta kawasan karst Kecamatan Ponjong ditunjukkan oleh Gambar 2.

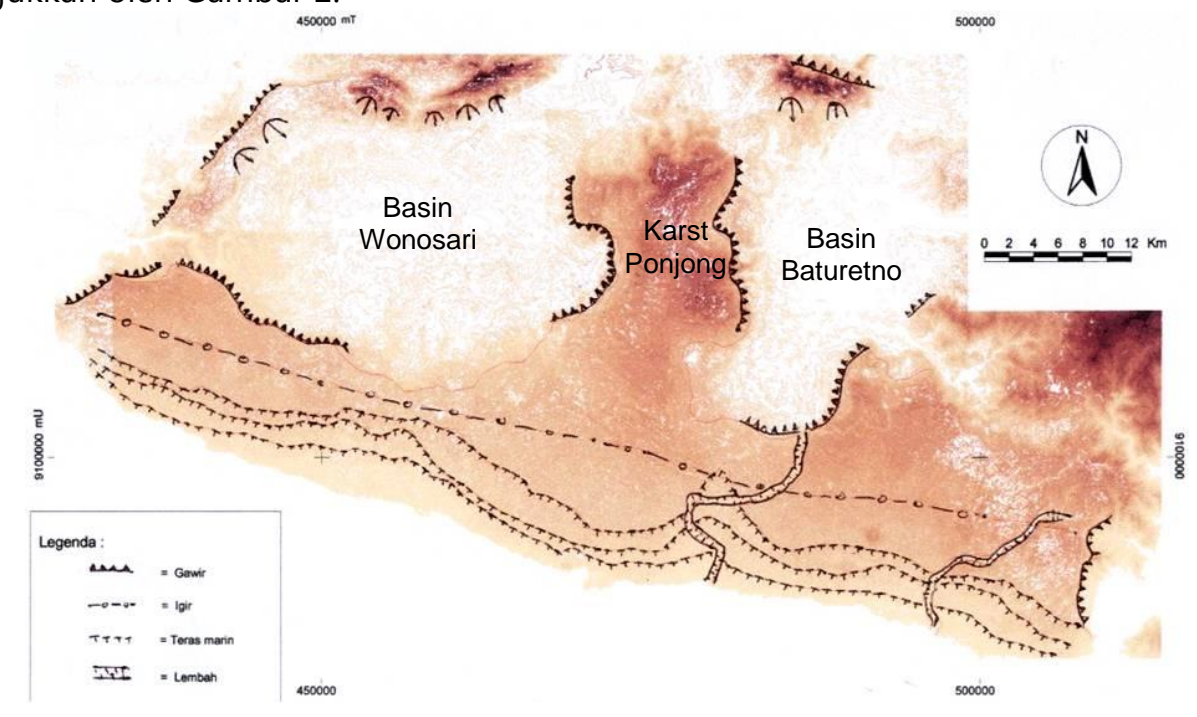

Gambar 1. Kedudukan Karst Ponjong terhadap Karst Gunungsewu (Haryono dkk, 2011: 5) 


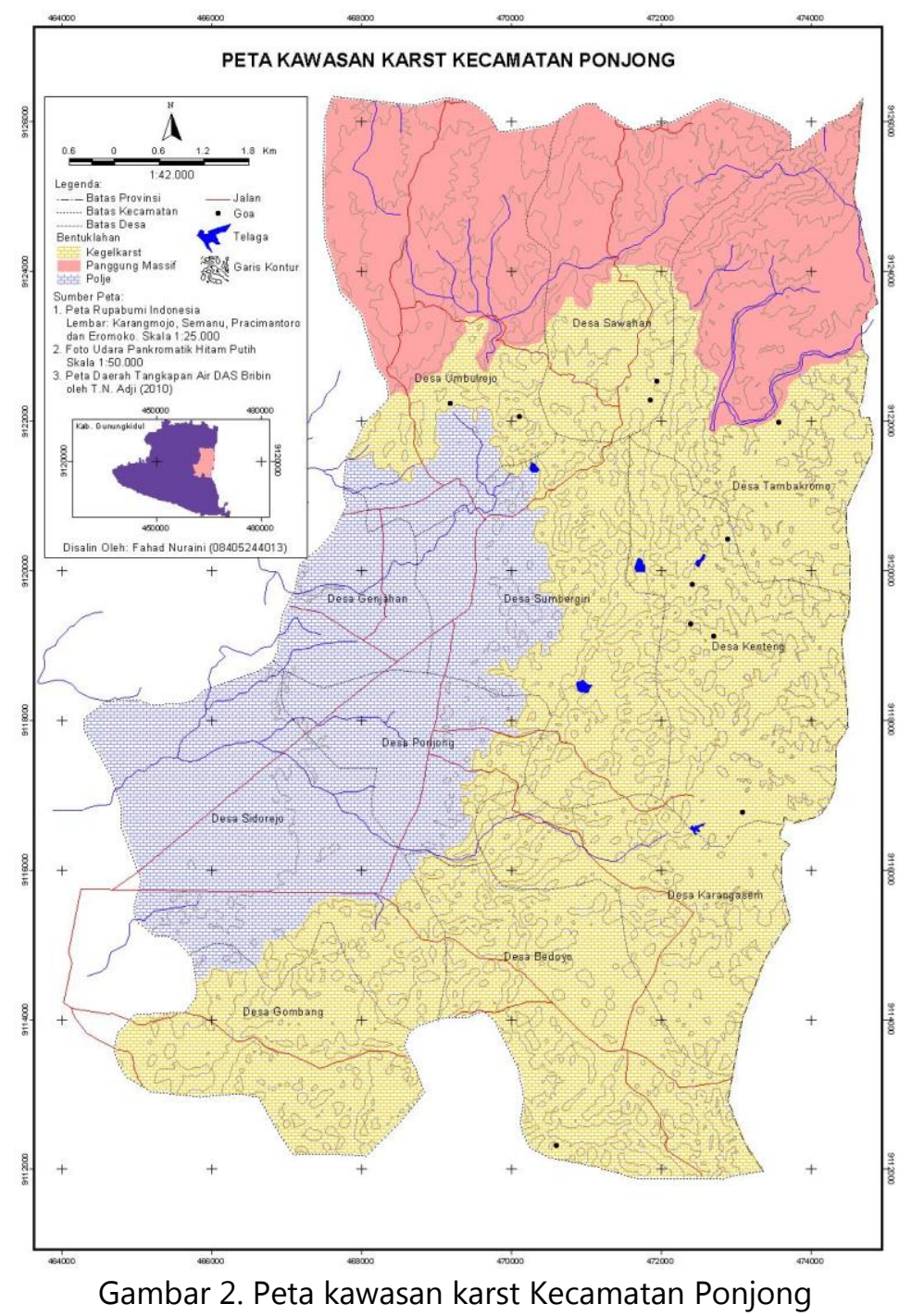

Formasi Wonosari merupakan formasi batuan penyusun Karst Ponjong. Formasi ini secara umum tersusun dari batu gamping terumbu (reef), batu gamping kristalin, batu gamping koral terumbu, dan batu gamping lempungan berusia Miosen Atas hingga Pliosen.Di Kecamatan Ponjong Formasi Wonosari Kawasan karst Kecamatan Ponjong tersusun oleh batu gamping terumbu (reef), batu gamping kristalin, batu gamping koral terumbu, dan batu gamping lempungan dari Formasi Wonosari (Bemmelen, 1970; Haryono, 2011; Haryono, 2000: 74). Formasi ini terdapat di sebagian besar wilayah Kecamatan Ponjong. Secara morfologi karst yang ada di Kecamatan Ponjong ini bertipe karst bukit dan menara (Haryono, 2000: 4). Hal ini merupakan karakteristik dari karst yang ada di daerah tropis dengan tingkat solusional yang telah berlangsung intensif. Secara hidrologi, Kecamatan Ponjong memiliki sistem hidrologi karst yang disebut Sub-Sistem Ponjong. Di wilayah ini terdapat delapan pemunculan dengan debit yang berbeda, lima diantaranya adalah Beton (100,9 liter/detik), Gremeng (1.870 liter/detik), Bendungan (326,5 liter/detik), Gedaren (27,6 liter/detik), dan Ponjong (40,6 liter/detik) (Haryono, 2011:80). Selain bagian dari Sub-Sistem Ponjong, sebagian wilayah Kecamatan Ponjong termasuk ke dalam Sub-Sistem Bribin-Baron-Ngobaran. 


\section{Karakteristik dan potensi fisik-non fisik Karst Ponjong}

Berdasarkan variasi morfologinya, Karst Ponjong dapat dibedakan kedalam empat zona (wilayah) yaitu zona utara, zona timur, zona tengah, dan zona selatan. Keempat zona ini digunakan sebagai dasar pembagian wilayah dalam mengidentifikasi karakteristik dan potensi untuk pengambangan ekowisata baik fisik maupun non fisik. Potensi fisik kawasan karst yang dikaji dalam penelitian ini meliputi aspek geomorfologi dan aspek hidrologi. Adapun potensi non fisik meliputi kondisi sosial-ekonomi-budaya, kearifan lokal, dan potensi SDM masyarakat.

Zona Utara merupakan kawasan dengan karakteristik fisik dan non fisik yang beragam dengan kelas kawasan karst I dan nilai lanskap A. Kawasan Karst Kelas I merupakan kawasan dengan kriteria: (1) berfungsi sebagai penyimpan air bawah tanah secara tetap (permanen) dalam bentuk akuifer, sungai bawah tanah, telaga atau danau bawah tanah yang keberadaannya mencukupi fungsi umum hidrologi; (2) Mempunyai gua-gua dan sungai bawah tanah aktif yang kumpulannya membentuk jaringan baik mendatar maupun tegak yang sistemnya mencukupi fungsi hidrologi dan ilmu pengetahuan; (3) Gua-guanya mempunyai speleotem aktif dan atau peninggalanpeninggalan sejarah sehingga berpotensi untuk dikembangkan menjadi objek wisata dan budaya; (4) Mempunyai kandungan flora dan fauna khas yang memenuhi arti dan fungsi sosial, ekonomi, budaya serta pengembangan ilmu pengetahuan. Adapun nilai lanskap A menunjukkan kawasan dengan kualitas tinggi dari aspek bentuklahan, vegetasi, air, warna, kelangkaan, maupun modifikasi yang telah dilakukan manusia.

Pada zona utara, kenampakan morfologi eksokarst yang berupa dolin dengan tipe mangkuk (Gambar 3a), bukit karst tipe menara dan kubah, serta lembah dengan tipe lembah kering, lembah saku, dan lembah allogenic. Kenampakan endokast berupa gua dengan tipe phreatic dan fracture(Gambar 3b), serta pemunculan air dengan tipe conduit(Gambar 3c).Gua dan luweng merupakan kenampakan yang dominan dan khas pada zona ini. Potensi fisik pada zona utara dapat dikelompokkan menjadi Komplek Obyek Beton, Komplek Obyek Tambakromo-Sawahan yang terdiri dari kenampakan eksokarst dan endokarst. Berdasarkan karakteristik non fisiknya pada Zona Utara terdapat beragam seni budaya yang masih dilestarikan dan dilaksanakan. Pada Zona Utara juga terdapat banyak petilasan yang digunakan untuk ritual-ritual. Pembangunan dan kehidupan masyarakat tidak mempengaruhi kealamian alam. Potensi sosial yang dapat mendukung ekowisata anataralain sumberdaya manusia yang memadai, atraksi senibudaya, dan hasil pertanian serta kerajian.

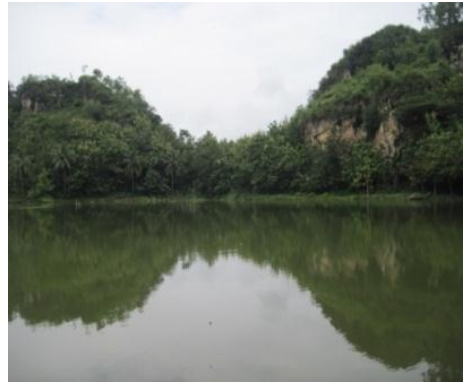

(a)

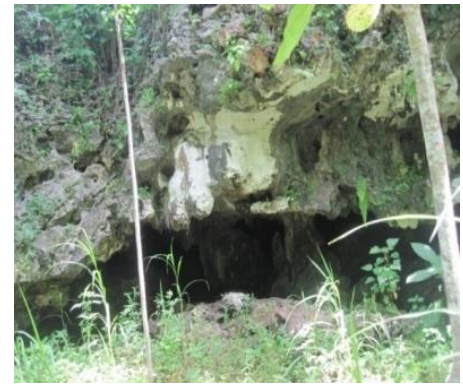

(b)

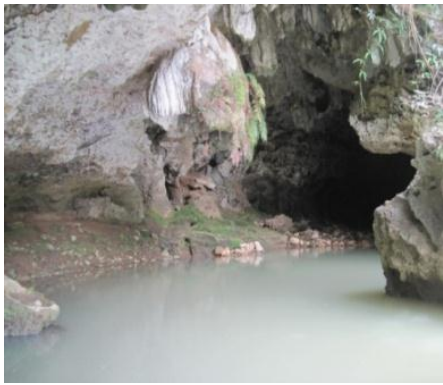

(c)

Gambar 3. Berbagai kenampakan fisik karst pada zona utara Karst Ponjong. (a) dolin tipe mangkuk yang membentuk Telaga Lawa, di Desa Sumbergiri, (b) Gua Saptorenggo bertipe fracture, di Desa Sawahan, (c) pemunculan air tipe conduit pada Gua Gremeng, di Desa Umbulrejo. 
Zona Tengah merupakan kawasan karst dengan karakteristik fisik yang tidak begitu beragam, hal ini karena Zona Tengah didominasi oleh bentuklahan polje dan bukit karst hanya terdapat di sebagian kecil wilayah. Zona tengah Memiliki kelas kawasan II dengan lanskap A. Kelas kawasan II memiliki kriteria: (1) Berfungsi sebagai pengimbuh air bawah tanah, berupa daerah tangkapan air hujan yang mempengaruhi naik-turunnya mukaair bawah tanah di kawasan kars, sehingga masih mendukung fungsi umum hidrologi; (2) Mempunyai jaringan lorong-lorong bawah tanah hasil bentukan sungai dan gua yang sudah kering, mempunyai speleotem yang sudah tidak aktif atau rusak, serta sebagai tempat tinggal tetap fauna yang semuanya memberi nilai dan manfaat ekonomi.

Kenampakan eksokarsrt didominasi oleh polje (Gambar 4a), sedangkan kenampakan endokarst didominasi pemunculan air (Gambar 4b). Pemunculan air yang memiliki debit besar antara lain dijumpai pada pemunculan air Ponjong dengan tipe diffuse. Sama seperti karakteristik fisiknya, karakteristik non fisik di Zona Tengah juga relatif tidak beragam karena pola kehidupan masyarakat cenderung sudah modern.Potensi yang ada berupa potensi ekonomi dalam bidang perikanan dan pertanian lahan basah. Selain potensi ekonomi wilayah Zona Tengah merupakan kawasan yang memiliki nilai sejarah dan Hindu-Budha.

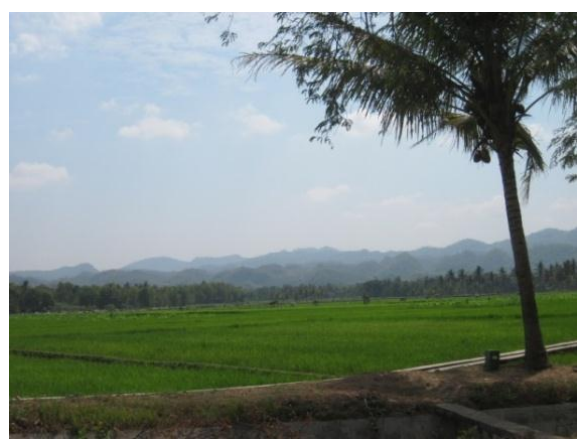

(a)

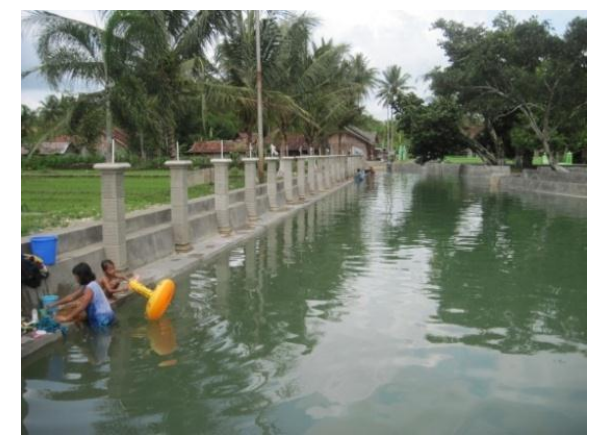

(b)

Gambar 4. Berbagai kenampakan fisik karst pada zona Tengah Karst Ponjong. (a) Polje yang dimanfaatkan untuk pertanian, (b) Pemunculan air sumber Ponjong di Desa Sumber

Zona selatan merupakan kawasan karst dengan kelas kawasan karst II dengan lanskap B. Nilai lanskap B menunjukkan kawasan dengan kualitas sedang dari aspek bentuklahan, vegetasi, air, warna, kelangkaan, maupun modifikasi yang telah dilakukan manusia. Zona selatan memiliki kenampakan fisik dan non fisik yang tidak beragam namun berbeda dengan daerah lainnya. Bukit karst di Zona Selatan bertipe menara (gambar 5) dengan kenampakan eksokarst yang mendominasi berupa telaga dengan tipe mangkuk dan corong, selain itu berupa lembah kering yang dimanfaatkan masyarakat untuk pertanian lahan kering. Kenampakan endokarst berupa gua dengan tipe pit cave. Karakteristik non fisik tidak begitu beragam bahkan sama dengan daerah lain hal ini, sehingga yang mendukung untuk ekowisata berupa pengolahan makanan khas dari hasil pertanian. 


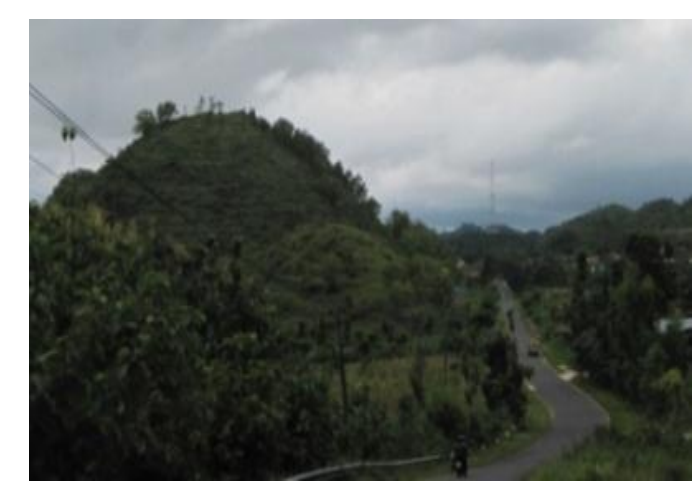

Gambar 5. Bukit Karst tipe Menara di Desa Bedoyo

Zona Timur merupakan kawasan karst kelas I dengan lanskap B. Zona timur merupakan kawasan dengan bentuk lahan bukit karst dengan tipe kubah. Kenampakan eksokarst dan endokarst tidak begitu beragam antara lain telaga dengan tipe mangkuk dan gua dengan tipe phreatic. Potensi fisik yang mendukung ekowisata antaralain Komplek Obyek Anjani yang terdiri dari Gua Gilap, Gua Rinjani (gambar 6a), dan Telaga Klumpit (gambar 6b). Karakteristik non fisik Zona Timur memiliki perbedaan tersendiri yaitu masyarakat yang masih tradisional dan memiliki kepercayaan adat istiadat serta mitos. Selain itu kawasan Zona Timur merupakan kawasan yang memiliki nilai sejarah.

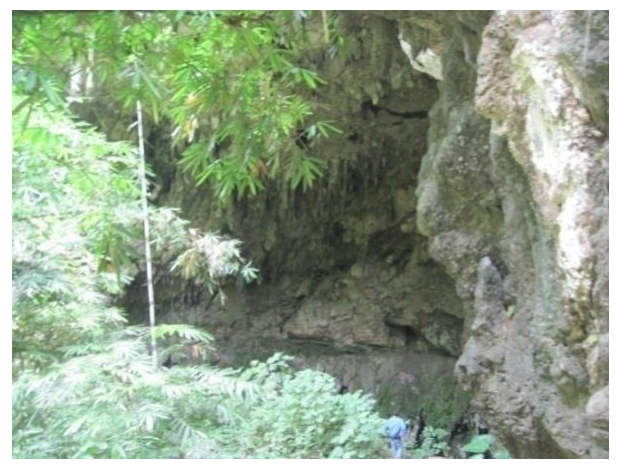

(a)

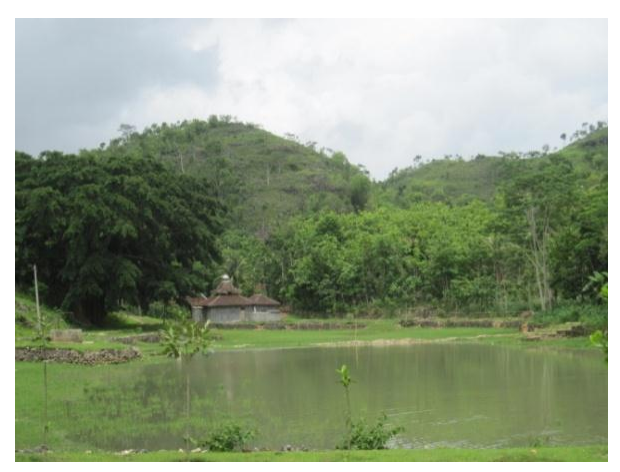

(b)

Gambar 6. Komplek Obyek Anjani di zona Timur

\section{Arahan Pengembangan Ekowisata Kecamatan Ponjong}

Tahap pertama dalam menyusun arahan pengembangan ekowisata di Kecamatan Ponjong adalah terlebih dahulu mengembangkan unsur fisik dan sosial yang berkaitan dengan pengembangan ekowisata. Unsur fisik meliputi (1) pengembangan tata ruang wilayah untuk wisata sesuai dengan kelas kawasan, (2) pengembangan area konservasi fisik dan hewan liar, dan (3) pengembangan sarana prasarana ekowisata. Adapun unsur sosial dapat dibedakan menjadi pengembangan sumberdaya manusia dan pengembangan ekonomi. Pengembangan sumberdaya manusia meliputi: pengetahuan masyarakat mengenai daerah karst, pengetahuan masyarakat mengenai ekowisata, pengembangan partisipasi dalam menyediakan jasa ekowisata, ketrampilan masyarakat dalam kesenian, kerajianan, dan pengolahan makanan. Adapun pengembangan ekonomi meliputi pengembangan sinergi pertukaran.

Setelah pengembangan tersebut, disusun desain pengembangan ekowisata yang meliputi perencanaan wilayah dan perencanaan infrastruktur dengan memperhatikan 
aspek lingkungan, kearifan lokal, dan sumberdaya manusia; perencanaan manajemen ekowisata; dan perencanaan partisipasi masyarakat. Perencanaan wilayah pada dalam pengembangan ekowisata di Kecamatan Ponjong antara lain berupa pembuatan zonasi dan kelas kawasan. Pembuatan kelas kawasan dimaksudkan untuk meminimalkan dampak negatif pariwisata sesuai dengan tujuan ekowisata yaitu untuk pelestarian dan konservasi. Penetapan zonasi diharapkan mampu memberikan kemudahan untuk pengembangan ekowisata dalam hal pembangunan sarana dan prasarana sesuai dengan potensi yang dimiliki.Pengembangan ekowisata di Kecamatan Ponjong menggunakan konsepintersystem yaitu adanya interaksi antar zona untuk saling melengkapi potensi sehingga mendukung satu sistem ekowisata. Bentuk wisata yang diterapkan yaitu Hard tourism (wisata minat khusus) yang merupakan bentuk operasi wisata dengan membatasi jumlah pengunjung.

Perencanaan infrastruktur dilakukan sesuai dengan nilai-nilai konservasi dan ekologi. Perencanaan infrastruktur ini menurut Nugroho (2011: 138) antara lain memperhatikan: bangunan fisik yang didesain dan dioperasikan secara hati-hati, infrastruktur tidak terbatas mendukung nilai-nilai konservasi, best practice dan lanskap; tetapi juga membantu tampilan arsitektur, pemahaman budaya, dan akses ke seremonia tradisi, kehidupan masyarakat, atau kearifan lokal. Kawasan Karst Kecamatan Ponjong merupakan daerah karst yang memiliki bangunan rumah yang khas yaitu rumah joglo kayu, menurut data monografi Kecamatan Ponjong tahun 2011 terdapat 3.496 rumah yang terbuat dari papan kayu. Rumah joglo kayu sangat serasi dengan alam, saat musim panen pemandangan rumah bertambah indah dengan hasil panen jagung yang dijajar pada bilik kayu depan rumah, dan padi gogo yang dijemur di depan rumah. Rencana desain infrastruktur dan pengembangan ekowisata di lingkungan kawasan karst Kecamatan Ponjong ditunjukkan oleh Tabel 1.

Tabel 1. Desain Arahan Perencanaan Pembangunan Infrastruktur dan Pengembangan Ekowisata

\begin{tabular}{|l|l|}
\hline \multicolumn{1}{|c|}{ Aspek } & \multicolumn{1}{|c|}{ Aktivitas } \\
\hline $\begin{array}{l}\text { Perencanaan dampak } \\
\text { lingkungan }\end{array}$ & $\begin{array}{l}\text { Analisis dampak lingkungan sebelum penerapan } \\
\text { ekowisata }\end{array}$ \\
\hline Desain dan lanskap & $\begin{array}{l}\text { Pengembangan management plan: hubungan } \\
\text { antar zona dan tukar materi sumberdaya } \\
\text { Pengembangan site plan. minimalisasi gangguan } \\
\text { Tree managemen: menghutankan kembali area } \\
\text { tamabang, menambah jumlah satwa, mengadakan } \\
\text { kembali satwa yang punah seperti rusa } \\
\text { Harmonisasi fasilitas dengan lingkungan }\end{array}$ \\
\hline $\begin{array}{l}\text { Fasilitas bangunan, } \\
\text { material, dan konsumsi } \\
\text { sumberdaya }\end{array}$ & $\begin{array}{l}\text { Desain bangunan sesuai dengan rumah tradisional } \\
\text { Yogyakarta yaitu joglo dengan bilik kayu dengan } \\
\text { fasilitas yang standar internasional namun hemat } \\
\text { energi. }\end{array}$ \\
\hline Teknologi & Teknologi modern namun ramah lingkungan \\
\hline $\begin{array}{l}\text { Hubungan dengan } \\
\text { penduduk lokal }\end{array}$ & $\begin{array}{l}\text { Wisatawan diajak bersama dalam kegiatan } \\
\text { penduduk lokal }\end{array}$ \\
\hline
\end{tabular}

Sumber: Hasil analisis sesuai dengan panduan pengembangan menurut Eagles et al dalam Nugroho 2011:145-146 
Perencanan partisipasi masyarakat dilakukan dengan: (1) program pelaksanaan ekowisata dengan masyarakat (keterlibatan awal), yaitu dengan mendiskusikan kajian kawasan karst pada masyarakat, memperkirakan bagaimana masyarakat akan merespon kegiatan ekowisata, menentukan stakeholder yang mampu memantau proses kegiatan ekowisata. (2) perencanaan awal: menggambarkan tujuan dari kegiatan ekowisata yang akan dicanangkan kepada masyarakat. (3) program pengembangan partisipasi masyarakat: program pengembangan partisipasi dengan pelatihan dan penyuluhan. (4) program implementasi: sosialisasi program dan kegiatan ekowisata secara rinci. (5) Review Setelah keterlibatan masyarakat: mengembangakan kebijakan sesuai dengan pendapat masyarakat bagaimana jalannya pelaksanaan ekowisata.

Sararan pelaksanaan kegiatan ekowisata meliputi kawasan karst, masyarakat, dan wisatawan, dalam hal ini sasaran juga termasuk dalam perencanaan ekowisata yang menjadi acuan garis pedoman keberhasilan pelaksanaan ekowisata. Sasaran kegiatan ekowisata Kecamatan Ponjong ditunjukkan pada Tabel 2.

Tabel 2. Sasaran Pelaksanaan Kegiatan Ekowisata Kecamatan Ponjong

\begin{tabular}{|l|l|}
\hline Sasaran & \multicolumn{1}{|c|}{ Garis Pedoman } \\
\hline Wilayah karst & Konservasi pelestrian dan pengelolaan \\
\hline Masyarakat & $\begin{array}{l}\text { Pengetahuan masyarakat tentang daerah kawasan } \\
\text { karst } \\
\text { - Penghasilan masyarakat meningkat }\end{array}$ \\
\hline Wisatawan & $\begin{array}{l}\text { Nilai pengetahuan, keindahan, dan makna yang di } \\
\text { peroleh setelah berkunjung }\end{array}$ \\
\hline
\end{tabular}

Ekowisata tidak lepas dari peranan masyarakat setempat, dari hasil wawancara dengan masyarakat, 90\% masyarakat setuju dengan pengembangan ekowisata dan $86 \%$ bersedia berpartisipasi dalam kegiatan ekowisata. Hasil wawancara dengan stakeholder $100 \%$ juga setuju dengan pengembangan ekowisata.Masyarakat dan pemerintah setempat berasumsi bahwa ekowisata merupakan upaya yang tepat dalam pelestarian kawasan karst selain itu dapat memberikan solusi yang tepat untuk ekonomi masyarakat. Berdasarkan anaisis matching obyek fisik dan sosial pada keempat zona di kawasan Karst Ponjong sesuai untuk pengembangan ekowisata. Obyek-obyek yang diidentifikasi dapat mendukung aspek scientific, aestetic, maupun philosophical dalam pengembangan ekowisata. Analisis matching (pencocokan) ditunjukkan oleh Tabel 3 dan Tabel 4. Arahan pengembangan ekowisata di tunjukkan pada Gambar 7. 
Tabel 3. Matrik Analisis Mathcing antara Obyek Fisik dengan Parameter Ekowisata di Kecamatan Ponjong

\begin{tabular}{|c|c|c|c|c|c|c|}
\hline \multirow{2}{*}{ Zona } & \multirow[t]{2}{*}{ Obyek Fisik } & \multicolumn{3}{|c|}{ Ekowisata } & \multicolumn{2}{|c|}{ Kesesuaian } \\
\hline & & Scientific (Pengetahuan) & Aestetic (keindahan) & $\begin{array}{c}\text { Philosophical } \\
\text { (nilai dan makna) }\end{array}$ & Sesuai & $\begin{array}{l}\text { Tidak } \\
\text { Sesuai }\end{array}$ \\
\hline $\begin{array}{l}\text { Zona } \\
\text { Utara }\end{array}$ & $\begin{array}{l}\text { 1. Telaga : Lawa } \\
\text { dan } \\
\text { Sawahombo } \\
\text { 2. Pemunculan } \\
\text { air: Beton dan } \\
\text { Nggremeng } \\
\text { 3. Gua: Lawa, } \\
\text { Nggremeng, } \\
\text { Paesan, } \\
\text { Saptorenggo }\end{array}$ & $\begin{array}{l}\text { 1. Perbedaan telaga dengan } \\
\text { sumbangan air yang mengisi dari } \\
\text { aliran limpasan hujan pada } \\
\text { Telaga Lawa, sedangkan pada } \\
\text { Telaga Sawahombo dari sungai } \\
\text { allogenic Petung dan aliran } \\
\text { limpasan sehingga Telga } \\
\text { Sawahombo lebih luas. Selain itu } \\
\text { tipe dolin juga mempengaruhi. } \\
\text { 2. Pemunculan air Beton dan } \\
\text { nggremeng yang bertipe conduit } \\
\text { 3. Gua Lawa, Nggremeng, Paesan, } \\
\text { dan Saptorenggo memiliki } \\
\text { kondisi keberadaan sistem aliran } \\
\text { bawah tanah yang berbeda-beda } \\
\text { dengan tipe yang sama. }\end{array}$ & $\begin{array}{l}\text { 1. Telaga Lawa dikelilingi oleh bukit bertipe menara yang } \\
\text { menjulang, dan diapit oleh Bendungan Beton dan Gua } \\
\text { Lawa. Telaga Sawahombo memiliki nilai aestetic yang } \\
\text { indah dengan kondisi telaga yang luas, dan } \\
\text { keberadaannya didukung latar pemandangan } \\
\text { Pegunungan Panggung Massif. } \\
\text { 2. Pemunculan air Beton dibendung menjadi sebuah } \\
\text { bendungan luas dengan dikelilingi bukit. Dan } \\
\text { disekitarnya di tanami cemara. Nggremeng memiliki } \\
\text { nilai keindahan dengan berhubungan dengan Luweng } \\
\text { Cokro dan memiliki lembah saku. } \\
\text { 3. Gua Lawa memiliki ruang gua yang besar, dengan } \\
\text { pemandangan kelelawar di dalamnya, Gua Paesan } \\
\text { memiliki warna stalaktit stalakmit cokelat muda, yang } \\
\text { berbeda dengan gua lainnya. Gua Saptorenggo } \\
\text { memiliki bentuk stalaktit dan stalakmit yang kahas } \\
\text { yaitu bentuk arca }\end{array}$ & $\begin{array}{l}\text { Memiliki nilai makna } \\
\text { pengetahuan bahwa } \\
\text { kenampakan karst memiliki } \\
\text { fungsi bagi kehidupan } \\
\text { sehingga perlu untuk } \\
\text { dilestariakan. Selain itu } \\
\text { pada obyek fisik dan sosial, } \\
\text { keindahan, dan makna rasa } \\
\text { syukur dan kekaguman } \\
\text { terhadap yang Maha } \\
\text { Pencipta }\end{array}$ & Sesuai & \\
\hline $\begin{array}{l}\text { Zona } \\
\text { Timur }\end{array}$ & $\begin{array}{l}\text { 1. Telaga Klumpit } \\
\text { 2. Gua: Gilap dan } \\
\text { Rinjani }\end{array}$ & $\begin{array}{l}\text { 1. Telaga Klumpit yang bertipe } \\
\text { mangkuk dengan aliran air } \\
\text { limpasan yang mengisi } \\
\text { 2. Gua Gilap dan Rinjani } \\
\text { merupakan gua kondisi basah } \\
\text { dengan sistem aliran bawah } \\
\text { tanah }\end{array}$ & $\begin{array}{l}\text { 1. Telaga Klumpit memiliki keindahan berdampingan } \\
\text { dengan permukiman penduduk sehingga } \\
\text { dimanfaatkan oleh penduduk untuk kebutuhan sehari- } \\
\text { hari dan pemandangan masyarakat yang harmonis } \\
\text { dengan alam } \\
\text { 2. Gua Gilap dan Rinjani dengan stalaktit dan stalakmit } \\
\text { yang khas berwarna abu-abu denagn tumbuhan lumut } \\
\text { yang ada di mulut gua dan populasi kera di sekitar } \\
\text { gua. }\end{array}$ & $\begin{array}{l}\text { Memiliki nilai cerita } \\
\text { legenda dan mitos dan } \\
\text { makna rasa syukur dan } \\
\text { kekaguman terhadap yang } \\
\text { Maha Pencipta }\end{array}$ & Sesuai & \\
\hline
\end{tabular}




\begin{tabular}{|c|c|c|c|c|c|}
\hline $\begin{array}{l}\text { Zona } \\
\text { Selatan }\end{array}$ & $\begin{array}{l}\text { 1. Telaga: } \\
\text { Asemlulang, } \\
\text { Mendak, dan } \\
\text { Kedokan } \\
\text { 2. Gua Seropan } \\
\text { 3. Komplek bukit } \\
\text { Bedoyo karst } \\
\end{array}$ & $\begin{array}{l}\text { 1. Telaga dengan dua tipe } \\
\text { mangkuk dan corong } \\
\text { 2. Gua dengan dua tipe pit cave } \\
\text { 3. Bukit karst menara dengan } \\
\text { solusional tinggi }\end{array}$ & $\begin{array}{l}\text { 1. Telaga indah dengan bukit karst di sekitarnya dan } \\
\text { berada di tepi jalan alternatif provinsi } \\
\text { 2. Gua dengan aliran bawah tanah memiliki keunikan } \\
\text { tersendiri } \\
\text { 3. Bukit-bukit yang menjulang tinggi }\end{array}$ & $\begin{array}{l}\text { Memiliki nilai makna } \\
\text { pengetahuan,keindahan, } \\
\text { dan makna rasa syukur dan } \\
\text { kekaguman terhadap yang } \\
\text { Maha Pencipta }\end{array}$ & Sesuai \\
\hline $\begin{array}{l}\text { Zona } \\
\text { Tengah }\end{array}$ & $\begin{array}{l}\text { 1. Pemunculan } \\
\text { air Sumber } \\
\text { 2. Pemandangan } \\
\text { Polje Ponjong }\end{array}$ & $\begin{array}{l}\text { 1. Pemunculan air tipe diffuse di } \\
\text { kawasan polje } \\
\text { 2. Daerah karst memiliki polje } \\
\text { yang subur dan hijau sepanjang } \\
\text { tahun, yang merupakan polje } \\
\text { struktural yang di pengaruhi } \\
\text { oleh aktivitas sesar dan bentuk } \\
\text { lahan di sekityarnya }\end{array}$ & $\begin{array}{l}\text { Berada di tengah hamparan sawah irigasi. Pemandangan } \\
\text { yang berbeda denagn dearah karst lain karena hijau } \\
\text { sepanjang tahun }\end{array}$ & $\begin{array}{l}\text { Makana keindahan, } \\
\text { penetahuan makna rasa } \\
\text { syukur dan kekaguman } \\
\text { terhadap yang Maha } \\
\text { Pencipta }\end{array}$ & Sesuai \\
\hline
\end{tabular}

Sumber: Hasil Analisis Menurut Mohamad Baiquni dalam Haryono(2011: 134-135)

Tabel4. Matrik Analisis Mathcing antara Obyek Sosial dengan Parameter Ekowisata di Kecamatan Ponjong

\begin{tabular}{|c|c|c|c|c|c|c|}
\hline \multirow[t]{2}{*}{ Zona } & \multirow[t]{2}{*}{ Obyek } & \multicolumn{3}{|c|}{ Ekowisata } & \multicolumn{2}{|c|}{ Kesesuaian } \\
\hline & & Scientific (Pengetahuan) & Aestetic(keindahan) & $\begin{array}{l}\text { Philosophical } \\
\text { (nilai dan } \\
\text { makna) }\end{array}$ & Sesuai & Tidak \\
\hline $\begin{array}{l}\text { Zona } \\
\text { Utara }\end{array}$ & $\begin{array}{l}\text { 1. Kesenian: Tayuban, ledek, jatilan, } \\
\text { reog chotil, wayang kulit, } \\
\text { campusari } \\
\text { 2. Adat kebiasaan: } \\
\text { Memagari mulut luweng, } \\
\text { menghutankan bukit karst, } \\
\text { membuat bendungan } \\
\text { permunculan air, Tidak } \\
\text { menebang pohon disekitar } \\
\text { pemunculan air } \\
\text { 3. Upacara adat: Rasulan }\end{array}$ & $\begin{array}{l}\text { 1. Kesenian yang beragam dapat diketahui dan } \\
\text { dipelajari oleh pengunjung } \\
\text { 2. Pada daerah karst ada adat dan kebiasaan yang } \\
\text { dapat menjaga kelestarian kawasan karst } \\
\text { 3. Upacara adat dapat memberikan pengetahuan } \\
\text { baru tentang nilai-nilai budaya yang } \\
\text { berhubungan dengan rasa syukur. }\end{array}$ & $\begin{array}{l}\text { 1. Memiliki keindahan seni manusia } \\
\text { yang berupa atraksi seperti reog } \\
\text { chotil yang khas pada Kawasan } \\
\text { Karst Kecamatan Ponjong. } \\
\text { 2. Harmonisasi antara manusia dan } \\
\text { lingkungnnya } \\
\text { 3. Pemandangan arak-arakan dan } \\
\text { gunungan serta rangkaian } \\
\text { kesenian pada upacara rasulan } \\
\text { memberikan pemandangan yang } \\
\text { berbeda dengan upacara- } \\
\text { upacara di tempat lainnya. }\end{array}$ & $\begin{array}{l}\text { Makna budaya } \\
\text { hasil interaksi } \\
\text { antara alam } \\
\text { dengan } \\
\text { manusia yang } \\
\text { memiliki nilai } \\
\text { sejarah budaya } \\
\text { dan terbentuk } \\
\text { dalam waktu } \\
\text { lama. Sehingga } \\
\text { perlu untuk } \\
\text { dilestarikan }\end{array}$ & Sesuai & \\
\hline
\end{tabular}




\begin{tabular}{|c|c|c|c|c|c|}
\hline $\begin{array}{l}\text { Zona } \\
\text { Timur }\end{array}$ & $\begin{array}{l}\text { 1. Kesenian: reog, karawitan, jatilan, } \\
\text { wayang kulit, ketoprak, } \\
\text { campursari, terbangan,cerita } \\
\text { rakyat dan legenda } \\
\text { 2. Adat kebiasaan } \\
\text { Bukit karst dihutankan, } \\
\text { mengkramatkan luweng, tidak } \\
\text { menambang bukit,tidak } \\
\text { menebang pohon disekitar } \\
\text { pemunculan air dan bukitkarst, } \\
\text { memanfaatkan telaga untuk } \\
\text { kebutuhan sehari-hari } \\
\text { 3. Upacara bersih desa }\end{array}$ & $\begin{array}{l}\text { 1. Kesenian memberikan pengetahuan pada } \\
\text { pengunjung mengenai kesenian pada daerah } \\
\text { karst } \\
\text { 2. Adat dan kebiasaan masyarakat yang selalu } \\
\text { berinteraksi langsung dengan lingkungan } \\
\text { memeberikan pengetahuan baru tentang nilai- } \\
\text { nilai dan fungsi lingkungan yang selalu } \\
\text { mendukung kehidupan } \\
\text { 1. Cerita dan legenda yang berkembang di } \\
\text { masyarakat memberikan pengetahuan baru } \\
\text { mengenai budaya seni pewayangan di jawa yang } \\
\text { juga dianggap berhubungan dengan keberadaan } \\
\text { suatu tempat seperti Gua Gilap dan Rinjani } \\
\text { 2. Cerita Pelarian Raja Majapahit dan Pengikutnya } \\
\text { Joko Umbaran yang memberikan nilai } \\
\text { pengetahuan sejarah di Zona Timur } \\
\text { 3. Upacara sebagian bentuk syukur yaitu bersih } \\
\text { desa memberikan pengetahuan bahwa rasa } \\
\text { syukur dapat di wujudkan dengan merawat dan } \\
\text { menjaga lingkungan }\end{array}$ & $\begin{array}{l}\text { 1. Keindahan seni atraksi yang khas } \\
\text { pada Zona Timur khususnya } \\
\text { wayang yang berhubungan } \\
\text { dengan cerita legenda Gua Gilap } \\
\text { dan Rinjani } \\
\text { 2. Interaksi masyarakat dan } \\
\text { lingkungannya dengan } \\
\text { memanfaatkan Telaga Klumpit } \\
\text { untuk aktivitas sehari-hari } \\
\text { memberikan pemandangan yang } \\
\text { menarik didukung } \\
\text { 3. Keindahan gua dengan did mampu } \\
\text { cerita rakyat kandahan } \\
\text { memberikan nilai keindahan } \\
\text { lebih pada pengunung }\end{array}$ & $\begin{array}{l}\text { Makna budaya } \\
\text { hasil interaksi } \\
\text { antara alam } \\
\text { dengan } \\
\text { manusia yang } \\
\text { memiliki nilai } \\
\text { sejarah budaya } \\
\text { dan terbentuk } \\
\text { dalam waktu } \\
\text { lama. Sehingga } \\
\text { perlu untuk } \\
\text { dilestarikan. }\end{array}$ & Sesuai \\
\hline $\begin{array}{l}\text { Zona } \\
\text { Selatan }\end{array}$ & $\begin{array}{l}\text { 1. Kesenian: reog, ketoprak, jatilan } \\
\text { 2. Adat kebiasaan: Bukit karst yang } \\
\text { ada songnya tidak boleh di } \\
\text { tambang } \\
\text { 3. Upacara adat: Nyadran, bersih } \\
\text { desa }\end{array}$ & $\begin{array}{l}\text { Pengetahuan masyarakat secara adat kebiasaan } \\
\text { pada bukit yang tidak boleh di tambang }\end{array}$ & Atraksi dari uapacara bersih desa & $\begin{array}{lr}\text { Makna budaya } \\
\text { hasil interaksi } \\
\text { antara alam } \\
\text { dengan } \\
\text { manusia }\end{array}$ & Sesuai \\
\hline $\begin{array}{l}\text { Zona } \\
\text { Tengah }\end{array}$ & $\begin{array}{l}\text { 1. Kesenian: ketoprak, salawatan, } \\
\text { reog cothil } \\
\text { 2. Adat kebiasaan: } \\
\text { Membuat bendungan } \\
\text { pemunculan air, tidak menebang } \\
\text { pohon disekitar pemunculan air } \\
\text { 3. Upacara adat rasulan }\end{array}$ & $\begin{array}{l}\text { Adat kebiasaan masyarakat dengan mengubah } \\
\text { sedikit kealamian pemunculan air memberikan } \\
\text { pengetahuan sebagai upaya pemanfaatan } \\
\text { sumberdaya air }\end{array}$ & $\begin{array}{l}\text { Harmonisasi lingkungan polje } \\
\text { dengan masyarakatnya mampu } \\
\text { memberikan nuansa daerah denagn } \\
\text { bentuk lahan yang sama dengan } \\
\text { daerah aluvial }\end{array}$ & $\begin{array}{lr}\text { Makna } & \text { budaya } \\
\text { hasil interaksi } \\
\text { antara alam } \\
\text { dengan } \\
\text { manusia }\end{array}$ & sesuai \\
\hline
\end{tabular}

Sumber: Hasil Analisis Menurut Mohamad Baiquni dalam Haryono(2011: 134-135) 
Pengembangan wisata pada Zona Utara mengutamakan kealamian alam tanpa mengubah dan menambah fasilitas yang dapat menimbulkan ketidak harmonisan, hal ini karena Zona Utara merupakan wilayah hinterland bagi zona lainnya. Strategi untuk pengembangan ekowisata pada Zona Utara ditunjukkan pada Tabel 5. Zona Utara merupakan zona untuk wisata jalur yang pertama. Dari hasil analisis, Kawasan Karst Zona Utara arahan pengembangan ekowisata dalam bentuk:

a. Wisata alam pengetahuan, study trip, dengan mengedepankan morfologi eksokarst dan endokarst. Wisata alam, dengan kegiatan wisata petualang, haiking, treking, caving, camping dan out bond

b. Wisata budaya dengan mengikuti kegiatan upacara rasulan

c. Pengembangan SDM untuk mengelola kegiatan ekowisata, dengan pendidikan danpelatihan-pelatihan

d. Manajemen yang baik agar nilai pelestarian dari ekowisata dapat tersampaikan pada wisatawan.

Tabel 5. Penerapan Startegi Pengembangan Ekowisata pada Zona Utara

\begin{tabular}{|c|c|c|}
\hline $\begin{array}{l}\text { Faktor-faktor } \\
\text { Internal }\end{array}$ & $\begin{array}{l}\text { Strength } \\
\text { (kekuatan) } \\
\text { Memiliki kelas kawasan karst I } \\
\text { dengan kualitas lanskap A } \\
\text { Keragaman vegetasi dan morfologi } \\
\text { yang menarik } \\
\text { Kearifan lokal yang masih dilestarikan } \\
\text { Pembangunan yang di lakukan tidak } \\
\text { mempengaruhi kealamian alam } \\
\text { Aksesibilitas menuju obyek telah } \\
\text { dibangun } \\
\text { Masyarakat mengerti kawasan karst } \\
\text { Ada pengembangan wisata }\end{array}$ & $\begin{array}{l}\text { Weaknes } \\
\text { (kelemahan) } \\
\text { Adanya penambangan gua } \\
\text { untuk pupuk guano } \\
\text { Pada obyek-obyek tertentu } \\
\text { mengalami kerusakan akibat } \\
\text { coret-coretan pada dinding } \\
\text { gua maupun pengambilan } \\
\text { stalaktit dan stalakmit } \\
\text { Kesadaran akan kealamian } \\
\text { alam masih kurang }\end{array}$ \\
\hline 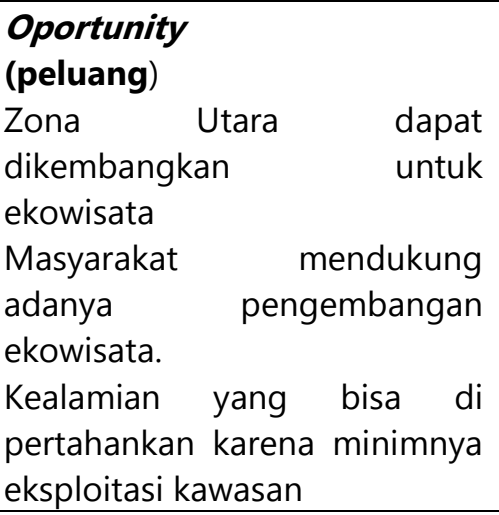 & $\begin{array}{l}\text { SO } \\
\text { Pengembangan ekowisata } \\
\text { bernuansa wisata alam dengan } \\
\text { memusatkan kegiatan pada alam } \\
\text { seperti caving, treeking, haiking, } \\
\text { dan study trip. }\end{array}$ & $\begin{array}{l}\text { WO } \\
\text { Pengembangan ekowisata } \\
\text { disertai dengan manajemen } \\
\text { ekowisata yang baik } \\
\text { dengan membuat aturan } \\
\text { bagi wisatawan dan rambu- } \\
\text { rambu pada tempat wisata. }\end{array}$ \\
\hline $\begin{array}{l}\text { Threat } \\
\text { (tantangan) } \\
\text { Penyiapan SDM untuk } \\
\text { mengelola ekowisata } \\
\text { Menjaga prinsip ekowisata } \\
\text { agar lestari }\end{array}$ & $\begin{array}{l}\text { ST } \\
\text { Penyiapan SDM r untuk } \\
\text { berpartsipasi dalam ekowisata } \\
\text { denagn pelatihan dan pendidikan } \\
\text { yang berbasis ekowisata }\end{array}$ & $\begin{array}{l}\text { WT } \\
\text { SDM yang dihasilkan } \\
\text { nantinya dapat } \\
\text { memberikan pengarahan } \\
\text { bagi wisatawan sehingga } \\
\text { konsep ekowisata dapat } \\
\text { tersampaikan }\end{array}$ \\
\hline
\end{tabular}


Arahan pengembangan ekowisata pada zona timur lebih ditekankan dalam bentuk phylosopycalyaitu dengan makna sejarah dan nilai budaya yang tinggi, obyek yang dapat di kunjungi yaitu Komplek Anjani meliputi Gua Gilap dengan habitat kera di sekitar gua, Gua Rinjani, dan Telaga Klumpit merupakan obyek memiliki cerita legenda. Pengunjung juga dapat menikmati homestay yang khas dan tradisional dan dapat berbaur mengikuti kegiatan penduduk lokal. Strategi untuk penerapan pengembangan ekowisata ditunjukkan pada Tabel 6. Wisata pada Zona Timur dalam bentuk:

a. Wisata sejarah dan budaya dengan mengunjungi obyek-obyek yang bernilai sejarah dan budaya seperti pada Gua Gilap dan Rinjani. Belajar kesenian khas kawasan karst.

b. Wisata rural untuk membentuk karakter merasakan hidup seperti masyarakat lokal yang jauh dari hiruk pikuk keramaian kota dengan kegiatan bercocok tanam pada lahan kering, makan makanan tradisional berupa tiwul, nasi jagung, merasakan air danau dolin klumpit.

c. Pembangunan sarana dan prasarana yang baik seperti jalan, homstay.

d. Pelestarian budaya pada masyarakat dengan partisipasi pertunjukan budaya dari setiap zona.

Tabel 6. Skema Penerapan Strategi Pengembangan Ekowisata pada Zona Timur

\begin{tabular}{|c|c|c|}
\hline $\begin{array}{l}\text { Faktor-faktor } \\
\text { Internal }\end{array}$ & $\begin{array}{l}\text { Strength } \\
\text { (kekuatan) } \\
\text { Kealamian alam terjaga } \\
\text { Tidak ada kegiatan pertambangan } \\
\text { pada bukit } \\
\text { Memiliki legenda dan budaya yang } \\
\text { khas } \\
\text { Kealamian alam dan bangunan } \\
\text { serta masyarakat yang ramah }\end{array}$ & $\begin{array}{l}\text { Weaknes } \\
\text { (kelemahan) } \\
\text { Pembangunan aksesibilitas } \\
\text { yang belum baik } \\
\text { Penyiapan SDM yang } \\
\text { profesional } \\
\text { Pelestarian budaya } \\
\text { Pengetahuan masyarakat } \\
\text { belum memadai }\end{array}$ \\
\hline $\begin{array}{l}\text { Oportunity } \\
\text { (peluang) } \\
\text { Kearifan lokal berupa budaya dan } \\
\text { legenda dapat di sumbangkan } \\
\text { menjadi potensi untuk ekowisata } \\
\text { Masyarakat yang ramah dapat } \\
\text { berbaur baik dengan wisatawan }\end{array}$ & 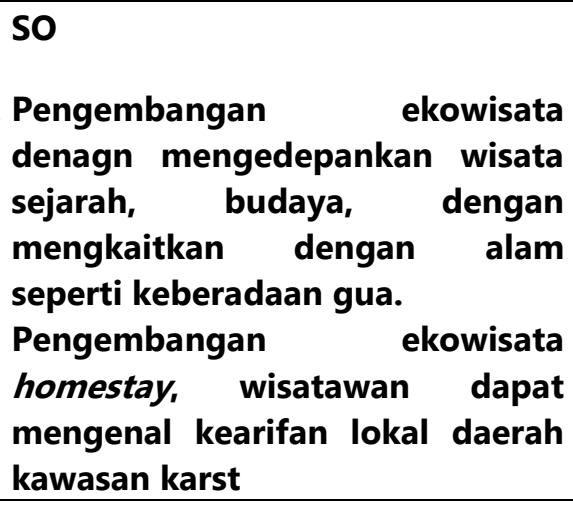 & 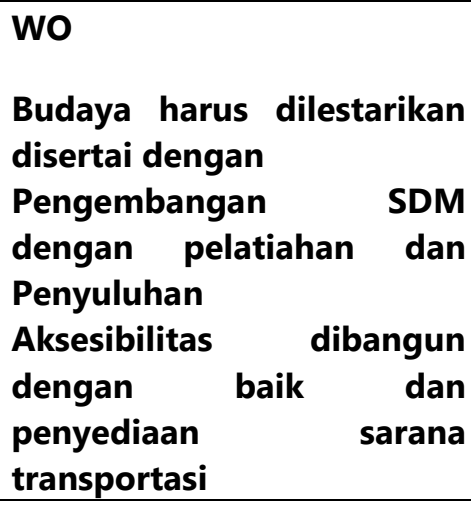 \\
\hline $\begin{array}{l}\text { Threat } \\
\text { (tantangan) } \\
\text { Pembangunan aksesibilitas yang } \\
\text { baik } \\
\text { Penyiapan SDM yang profesional } \\
\text { Pelestarian budaya kembali }\end{array}$ & $\begin{array}{l}\text { ST } \\
\text { Pembangunan homstay sesuai } \\
\text { dengan bangunan tradisional } \\
\text { kawasan karst dan } \\
\text { Pembangunan aksibilitas yang } \\
\text { baik }\end{array}$ & $\begin{array}{l}\text { WT } \\
\text { Budaya, alam dan SDM } \\
\text { yang baik mendukung } \\
\text { pengembangan ekowisata. }\end{array}$ \\
\hline
\end{tabular}

Sumber: Hasil analisis dan penyusunan strategi 
Zona Selatan merupakan zona kelas II dengan lanskap kualitas sedang, potensi fisik yang dimiliki berupa potensi bukit menara yang rapat dan menjulang tinggi, selain itu gua-gua yang memiliki lorong-lorong conduit dengan sistem aliran bawah tanah. Kegitaan wisata lebih mengedepankan nilai konservasi dan pengetahuan dikarenakan. Kawasan ini merupakan dengan karakteristik solusional tinggi dan banyak kegiatan tambang. Merupakan jalur wisata ke empat. Penerapan strategi untuk pengembangan ekowisata ditunjukkan pada Tabel 7. Pengembangan ekowisata dalam bentuk:

a. Wisata alam speoloegi yaitu wisata gua-gua, wisata alam dengan kegiatan trekking pada bukit-bukit dengan menara pandang di atas bukit.

b. Wisata alam konservasi, dengan setiap pengunjung menanam pohon yang sudah di sedoiakan pengelola, di bangun pula penagkaran rusa

c. Wisata oleh-oleh yang ada di tata sepanjang Telga Mendak, Asemlulang, dan Kedokan

d. Pelestarian kawasan bukit dengan pelarangan penambangan

e. Pembangunan fasilitas puast oleh-oleh dengan memberdayakan masyarakat untuk membuat variasi makanan khas dan kerajinan yang di produksi oleh masyarakat Kecamatan Ponjong.

Tabel 7. Skema Penerapan Strategi Pengembangan Ekowisata pada Zona Selatan

\begin{tabular}{|c|c|c|}
\hline $\begin{array}{l}\text { Faktor-faktor } \\
\text { Internal }\end{array}$ & $\begin{array}{l}\text { Strength } \\
\text { (kekuatan) } \\
\text { Memiliki morfografi bukit menara } \\
\text { Memiliki gua-gua dengan sistem } \\
\text { sungai bawah tanah dan telaga- } \\
\text { telaga yang mudah dalam akses } \\
\text { Berada di jalur antar provinsi } \\
\text { sehingga aksesibilitas mudah }\end{array}$ & $\begin{array}{l}\text { Weaknes } \\
\text { (kelemahan) } \\
\text { Merupakan daerah pertambangan } \\
\text { dan pengolahan batu gamping } \\
\text { Vegetasi yang tidak beragam } \\
\text { Saat musim kemarau sulit di } \\
\text { jumpai sumber air permukaan }\end{array}$ \\
\hline $\begin{array}{l}\text { Oportunity } \\
\text { (peluang) } \\
\text { Dapat di kembangkan untuk } \\
\text { ekowisata pada bukit dan dolin dan } \\
\text { pusat oleh-oleh }\end{array}$ & $\begin{array}{l}\text { SO } \\
\text { Penembangan ekowisatadi } \\
\text { tekankan padabukit, telaga dan } \\
\text { sistem bawah tanah. } \\
\text { pembangunan menara pandang } \\
\text { untuk melihat kawasan karst dari } \\
\text { ketinggian. } \\
\text { Pengembangan ekowisata yang } \\
\text { di tekankan pada pengetahuan } \\
\text { morfologi endokarst berupa } \\
\text { sungai bawah tanah. } \\
\text { Pembangunan pusat oleh-oleh. }\end{array}$ & $\begin{array}{l}\text { WO } \\
\text { Pengembangan ekowisata harus } \\
\text { di barengi dengan } \\
\text { perekontruksi bekas tambang } \\
\text { Dilakukan penyuluhan dan } \\
\text { penyadaran pada masyarakat } \\
\text { untuk menghentikan } \\
\text { penambangn } \\
\text { Rehabilitasi lahan bekas } \\
\text { tambang } \\
\begin{array}{l}\text { Mengfungsikan sumberdaya air } \\
\text { bawah tanah yang berada di } \\
\text { gua seropan }\end{array}\end{array}$ \\
\hline $\begin{array}{l}\text { Threat } \\
\text { (tantangan) } \\
\text { Menjaga kelestarian alam dari } \\
\text { aktivitas penambangan } \\
\text { Memberdayakan masyarakat dalam } \\
\text { pengolahan makanan khas } \\
\text { Membangun fasilitas pusat oleh-oleh }\end{array}$ & $\begin{array}{l}\text { ST } \\
\text { Pelestarian dan membangun } \\
\text { kesadaran masyarakat akan } \\
\text { kelestarian bukit karst. } \\
\text { Pusat poleh-oleh di tepi danau } \\
\text { dolin. }\end{array}$ & $\begin{array}{l}\text { WT } \\
\text { Kerjasama antara pemerintah } \\
\text { dengan masyarakat akan } \\
\text { berpeluang besar untuk } \\
\text { pengembangan ekowisata } \\
\text { Pembangunan sarana prasarana } \\
\text { Pelatihan dan penyuluhan }\end{array}$ \\
\hline
\end{tabular}

Sumber: Hasil analisis dan penyusunan strategi 
Zona Tengah merupakan zona dengan kelas kawasan II, dengan lanskap kualitas tinggi. Kegiatan wisata mengedepankan penetahuan nilai kawasan karst yang berupa polje yang subur. Zona Tengah memiliki obyek yang dapat di kembangakan dalam ekowisata antara lain Pemunculan air Sumber, Pemandian Gunung Kendil, kawasan polje yang subur dapat dibentuk agro tamanan pertanian dan perkebunan. Penerapan strategi pengembangan ekowisata pada Zona Tengah ditunjukkan pada Tabel 8. Bentuk ekowisata yang dapat dikembangkan adalah:

a. Wisata sejarah dan budaya, dengan mengunjungi situs peninggalan zaman HinduBudha

b. Wisata kuliner, agro wisata, karena didukung dengan sumber air yang melimpah

c. Wisata out bon pedesaan dengan kegiatan membajak sawak denagn kerbau, mancing

d. Pada Zona Tengah dibangun fasilitas berupa museum karst yang memuat penegtahuan kawasan karst umum maupun khusus kawasan karst Kecamatan Ponjong.

e. Penataan ruang kembali bangunan dan pertokoan

Tabel 8. Skema Penerapan Strategi Pengembangan Ekowisata pada Zona Tengah

\begin{tabular}{|c|c|c|}
\hline $\begin{array}{l}\text { Faktor-faktor } \\
\text { Internal }\end{array}$ & $\begin{array}{l}\text { Strength } \\
\text { (kekuatan) } \\
\text { Memiliki daearh polje yang luas } \\
\text { sehingga sumber air mudah di } \\
\text { temukan, dan pemandangan hijau } \\
\text { sepanjang tahun } \\
\text { Vegetasi beragam } \\
\text { Sumber air yang sudah di } \\
\text { amnfaatkan masyarakat untuk } \\
\text { budidaya ikan dan rumah makan } \\
\text { Fasilitas lengkap seperti pertokoan }\end{array}$ & $\begin{array}{l}\text { Weaknes } \\
\text { (kelemahan) } \\
\text { Moderenisasi telah } \\
\text { mempengaruhi kearifan lokal } \\
\text { pembangunan kurang selaras } \\
\text { dengan alam }\end{array}$ \\
\hline $\begin{array}{l}\text { Oportunity } \\
\text { (peluang) } \\
\text { Kuliner khas dan kuliner hasil } \\
\text { budidaya ikan dapat } \\
\text { menyumbangkan untuk ekowisata }\end{array}$ & $\begin{array}{l}\text { SO } \\
\text { Pengembangan ekowisata di } \\
\text { tekankan penetahuan, dengan } \\
\text { dibangun museum karst } \\
\text { kecamatan ponjong. Selain itu } \\
\text { hasil produksi budidaya ikan } \\
\text { mampu menambah produk } \\
\text { wisata kuliner untuk ekowisata }\end{array}$ & $\begin{array}{l}\text { WO Penataan ruang } \\
\text { yang baik menghasilkan } \\
\text { keselarasan dengan alam } \\
\text { Upaya } \\
\text { menyadarkan arti nilai } \\
\text { budaya pada masyarakat }\end{array}$ \\
\hline $\begin{array}{l}\text { Threat } \\
\text { (tantangan) } \\
\text { Penataan ruang yang lebih baik }\end{array}$ & $\begin{array}{l}\text { ST } \\
\text { Dibutuhkan perencanaan } \\
\text { pembangunan pada kawasan } \\
\text { polje agar tetap memperlihatkan } \\
\text { kehijauan. }\end{array}$ & $\begin{array}{l}\text { WT } \\
\text { Pembangunan } r \text { museum } \\
\text { karstobyek dan wisata } \\
\text { meningkatkan kesadaran } \\
\text { masyarakat mengenai } \\
\text { budaya kawasan karst dan } \\
\text { pengetahuan masyarakat } \\
\text { tentang karst }\end{array}$ \\
\hline
\end{tabular}

Sumber: Hasil analisis dan penyusunan strategi 


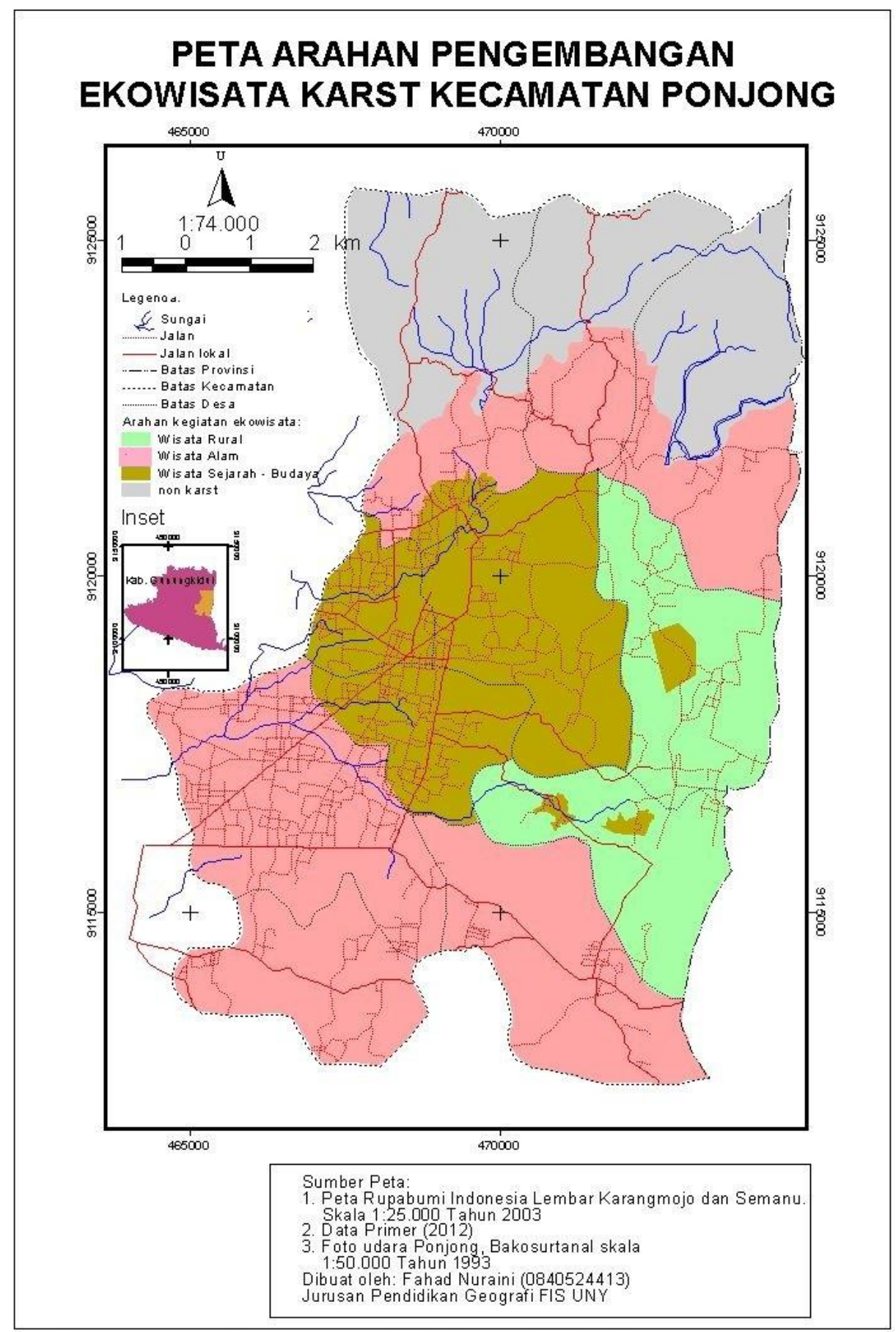

Gambar 7. Peta Arahan Pengembangan Ekowisata

\section{Kesimpulan}

Kawasan Karst di Kecamatan Ponjong memiliki potensi yang sangat beragam, potensi tersebut dapat dilihat dari karakteristik kawasan karst yang berupa kenampakan fisik dan kehidupan masyarakatnya. Kenampakan fisik kawasan karst di Kecamatan Ponjong dapat terbagi menjadi dua kelas kawasan karst yaitu kelas I dan kelas II. Sedangkan untuk nilai lanskap, kawasan karst di Kecamatan Ponjong memiliki nilai A dan 
B sehingga menarik untuk dikembangkan untuk obyek wisata. Karakteristik potensi fisik dan non fisik.

Zona Utara memiliki kelas kawasan karst I dan lanskap A. Potensi sosial yang dapat mendukung ekowisata anataralain yaitu sumberdaya manusia yang memadai, atraksi senibudaya, dan hasil pertanian serta kerajinan. Zona Tengah memiliki kelas kawasan II dengan lanskap A. Pola kehidupan masyarakat yang sudah modern memiliki potensi ekonomi dalam bidang perikanan dan pertanian lahan basah. Selain potensi ekonomi wilayah Zona Tengah merupakan kawasan yang memiliki nilai sejarah dan Hindu-Budha. Zona Selatan memiliki kawasan karst dengan kelas kawasan karst II dengan lanskap B. Karakteristik non fisik tidak begitu beragam bahkan sama dengan daerah lain hal ini, sehingga yang mendukung untuk ekowisata berupa pengolahan makanan khas dari hasil pertanian. Zona Timur merupakan kawasan karst kelas I dengan lanskap B. Karakteristik non fisik yaitu masyarakat yang masih tradisional dan memiliki kepercayaan adat istiadat serta mitos. Selain itu kawasan Zona Timur merupakan kawasan yang memiliki nilai sejarah.

Ekowisata merupakan salah satu upaya untuk pengembangan sekaligus pelestarian kawasan karst yaitu dengan memeperhatikan karakteristik potensi kawasan karst tersebut dengan parameter ekowisata. Pengembangan ekowisata daerah karst Kecamatan Ponjong dibagi menjadi empat zona sesuai dengan bentuklahan karst yang berkembang (utara, tengah, selatan, dan timur). Desain pengembangan ekowisata dengan: 1) pembuatan kelas kawasan zoning; 2) perencanaan infrastruktur; 3) perencanaan menejemen ekowisata; 3) pelaksanaan kegiatan ekowisata yang berkelanjutan berdasarkan karakteristik dan potensinya. Hasil dari analisis SWOT, pengembangan ekowisata di zona utara berupa wisata alam-pengetahuan, zona tengah wisata sejarah-budaya, zona selatan wisata alam-konservasi, zona timur wisata rural-budaya.

\section{Daftar Pustaka}

Eko Haryono. 2001. Nilai Hidrologi Bukit Karst. Seminar Nasional Eko-Hidrolik. Teknik Sipil Universitas Gadjah Mada, Yogyakarta 28-29 Maret 2001. ----. 2011. Atmospheric Carbon Dioxide Sequestration Trough Karst Denudation Processes. Artikel. Proceedings Asian Trans-Disciplinary Karst Conference.

2000. Sumberdaya Alam di Kawasan Pesisir dan Pulau-pulau Kecil Berbatuan Karbonat, Telaah Singkat Mengenai Potensi, Arahan Pengembangan, Konservasi dan Rehabilitasi. Seminar Nasional Pengelolaan Ekosistem Pantai dan Pulau-Pulau Kecil dalam Konteks Negara Kepulauan. Fakultas Geografi Universitas Gadjah Mada. Yogyakarta 2 September 2000.

2004. Geomorfologi Karst, dalam Eko Haryono dan Tjahyo Nugroho Adji (ed). 2004. Pengantar Geomorfologi dan Hidrologi Karst. Yogyakarta: Fakultas Geografi Universitas Gadjah Mada.

Mohhamad Baiquni. 2001 Ekowisata Kawasan Karst. Belajar dari Guilin Cina untuk Pengembangan Wisata di Wonogiri. Pelatihan Pengelolaan Kawasan Karst Kabupaten Wonogiri. Wonogiri Juni 2001.

Sutikno dan Eko Haryono. 2000. Perlindungan Fungsi Kawasan Karst. Seminar Perlindungan Penghuni Kawasan Karst: masa lalu, masa kini, dan masa yang akan datang terhadap Fungsi Lingkungan Hidup. PSLM UNS. Surakarta 11 November 2000. 